\title{
In-situ biogas upgrading in thermophilic granular UASB reactor: key factors affecting the hydrogen mass transfer rate
}

Bassani, Ilaria; Kougias, Panagiotis; Angelidaki, Irini

Published in:

Bioresource Technology

Link to article, DOI:

10.1016/j.biortech.2016.09.083

Publication date:

2016

Document Version

Peer reviewed version

Link back to DTU Orbit

Citation (APA):

Bassani, I., Kougias, P., \& Angelidaki, I. (2016). In-situ biogas upgrading in thermophilic granular UASB reactor: key factors affecting the hydrogen mass transfer rate. Bioresource Technology, 221, 485-491. https://doi.org/10.1016/j.biortech.2016.09.083

\section{General rights}

Copyright and moral rights for the publications made accessible in the public portal are retained by the authors and/or other copyright owners and it is a condition of accessing publications that users recognise and abide by the legal requirements associated with these rights.

- Users may download and print one copy of any publication from the public portal for the purpose of private study or research.

- You may not further distribute the material or use it for any profit-making activity or commercial gain

- You may freely distribute the URL identifying the publication in the public portal 


\section{In-situ biogas upgrading in thermophilic granular UASB}

\section{2 reactor: key factors affecting the hydrogen mass transfer rate}

3 Ilaria Bassani, Panagiotis G. Kougias ${ }^{*}$, Irini Angelidaki

4 Department of Environmental Engineering, Technical University of Denmark, Kgs.

5 Lyngby, Denmark

6

$7 \quad{ }^{*}$ Corresponding author: Panagiotis G. Kougias, Department of Environmental

8 Engineering, Technical University of Denmark, Bld 113, 2800 Lyngby, Denmark.

$9 \quad$ E-mail address: panak@env.dtu.dk, Tel.: +45 45251454 
Highlights

- Biogas upgrading to $82 \% \mathrm{CH}_{4}$ is feasible in a thermophilic granular UASB reactor.

- $\mathrm{H}_{2}$ is introduced in a separate chamber having a volume of $25 \%$ the reactor.

- $\mathrm{H}_{2}$ low gas-liquid mass transfer rate limits the availability of $\mathrm{H}_{2}$ for methanogens.

- $\mathrm{H}_{2}$ distribution can be improved using porous inert devices, like ceramic sponge.

- Gas recirculation and chamber configuration help to maximize $\mathrm{CO}_{2}$ conversion to $\mathrm{CH}_{4}$.

\section{Abstract}

Biological biogas upgrading coupling $\mathrm{CO}_{2}$ with external $\mathrm{H}_{2}$ to form biomethane opens new avenues for sustainable biofuel production. For developing this technology efficient $\mathrm{H}_{2}$ to liquid transfer is fundamental. This study proposes an innovative setup for in-situ biogas upgrading converting the $\mathrm{CO}_{2}$ in the biogas into $\mathrm{CH}_{4}$, via hydrogenotrophic methanogenesis. The setup consisted of a granular reactor connected to a separate chamber, where $\mathrm{H}_{2}$ was injected. Different packing materials (rashig rings and alumina ceramic sponge) were tested to increase gas-liquid mass transfer. This aspect was optimized by liquid and gas recirculation and chamber configuration. It was shown that by distributing $\mathrm{H}_{2}$ through a metallic diffuser followed by ceramic sponge in a separate chamber, having a volume of $25 \%$ of the reactor, and by applying a mild gas recirculation, $\mathrm{CO}_{2}$ content in the biogas dropped from 42 to $10 \%$ and the final biogas was upgraded from 58 to $82 \% \mathrm{CH}_{4}$ content.

\section{Keywords}


In-situ biogas upgrading; Hydrogen; Gas-liquid mass transfer rate; UASB; Granules;

Anaerobic digestion

\section{Introduction}

Anaerobic Digestion (AD) of organic waste is a promising technology for sustainable energy production (Weiland, 2010). The potato-starch processing industry produces, as byproduct, up to $1 \mathrm{~m}^{3}$ of potato juice per ton of potatoes (Abeling and Seyfried, 1993).

Potato-starch wastewater contains high concentration of biodegradable compounds, such as starch and proteins, suitable for biogas production via AD (Barampouti et al., 2005). Biogas typically contains $~ 50-70 \% \mathrm{CH}_{4}$ and $30-50 \% \mathrm{CO}_{2}$. Biogas upgrading to

$\mathrm{CH}_{4}$ content higher than $90 \%$ increases its heating value and its potential applications as alternative to natural gas (Deng and Hägg, 2010). physicochemical $\mathrm{CO}_{2}$ removal. Nevertheless, these technologies require use of additional materials and chemicals considerably increasing the cost of the process and energy input. Alternatively, biogas can be upgraded by biologically coupling $\mathrm{H}_{2}$, derived from water electrolysis, with $\mathrm{CO}_{2}$ present in the biogas to convert them to $\mathrm{CH}_{4}$. $\mathrm{H}_{2}$ can be produced using the electricity generated by the surplus of energy from wind mills or photovoltaic facilities, which may result from variable weather conditions. This reaction is carried out by a group of microorganisms known as hydrogenotrophic methanogenic archaea that utilize $\mathrm{CO}_{2}$, as carbon source, and $\mathrm{H}_{2}$, as electron donor, to produce $\mathrm{CH}_{4}$ via hydrogenotrophic methanogenesis (Muñoz et al., 2015). Previous 
20 to $40 \%$ increase in $\mathrm{CH}_{4}$ production rate, as result of the conversion of the $\mathrm{CO}_{2}$ present in the biogas to additional $\mathrm{CH}_{4}$ (Luo and Angelidaki, 2013; Luo et al., 2012). Although biological biogas upgrading offers economical and technical advantages compared to traditional methods (Nordberg et al., 2012), $\mathrm{H}_{2}$ mediated biogas upgrading is still challenging. One of the main limitations is the low $\mathrm{H}_{2}$ gas-liquid mass transfer rate (Bassani et al., 2015; Luo and Angelidaki, 2012; Luo et al., 2012). $\mathrm{H}_{2}$ gas-liquid mass transfer rate can be described by the following equation (1):

$$
r_{t}=22.4 k_{L} a\left(H_{2 g T h}-H_{2 l}\right)
$$

where $r_{t}$ (L/(L-day)) is the $\mathrm{H}_{2}$ gas-liquid mass transfer rate, $22.4(\mathrm{~L} / \mathrm{mol})$ is the gas volume to mole ratio ( 1 mol gas corresponds to $22.4 \mathrm{~L}$ at STP), $k_{L} a\left(\mathrm{day}^{-1}\right.$ ) is the gas transfer coefficient, $H_{2 g T h}(\mathrm{~mol} / \mathrm{L})$ represent the $\mathrm{H}_{2}$ concentration in the gas phase while $H_{2 l}(\mathrm{~mol} / \mathrm{L})$ the $\mathrm{H}_{2}$ dissolved in the liquid phase. One way to increase $\mathrm{H}_{2}$ gas-liquid mass transfer rate is by increasing $k_{L} a$. This coefficient is specific for given reactor configuration and operating conditions (Pauss et al., 1990). Therefore, $k_{L} a$ can be modulated by changing parameters such as mixing speed (Bhattacharyya and Singh, 2010; Luo and Angelidaki, 2012), gas recirculation (Guiot et al., 2011) and $\mathrm{H}_{2}$ diffusion device (Luo and Angelidaki, 2013; Díaz et al., 2015).

Besides, high-rate anaerobic treatment using up-flow anaerobic sludge blanket (UASB) reactors is commonly applied in industrial wastewater treatment plants (Gomec, 2010; Sevilla-Espinosa et al., 2010). Moreover, typically a UASB process is expected to provide higher methane content in the biogas than a CSTR process (Nizami et al., 2012).

UASB reactors' technology is based on the presence of granular sludge comprised of microorganisms responsible for catalyzing the biological conversion of organic matter 
to biogas. High recirculation flow rates and consequent high up-flow velocities have an in important role for the hydraulic mixing improving the wastewater to granules contact (Powar et al., 2013; Zheng et al., 2012). It has been previously reported that carbohydrate degraders and hydrogenotrophic methanogens are predominant in starchgrown granules, likely due to their role in the interspecies $\mathrm{H}_{2}$ transfer with syntrophic bacteria (Lu et al., 2015). Moreover, previous studies on $\mathrm{H}_{2}$ mediated biogas upgrading demonstrated that $\mathrm{H}_{2}$ affected the microbial community composition enhancing the hydrogenotrophic methanogenic pathway and the syntrophic relationship between bacteria and hydrogenotrophic methanogens (Bassani et al., 2015). In this study an innovative setup consisting of a UASB granular reactor connected to a separate chamber, where the $\mathrm{H}_{2}$ was injected, was designed to mediate efficient $\mathrm{H}_{2}$ transfer to liquid phase for biological conversion of $\mathrm{H}_{2}$ and $\mathrm{CO}_{2}$ to $\mathrm{CH}_{4}$. Key factors affecting the $\mathrm{H}_{2}$ gas-liquid mass transfer rate were evaluated. More specifically, the effect of different operating conditions aiming in increasing $k_{L} a$ of $\mathrm{H}_{2}$ to gas, and thereby increase the gas to liquid transfer, were studied to elucidate their role in improving $\mathrm{CO}_{2}$ and $\mathrm{H}_{2}$ conversion to $\mathrm{CH}_{4}$. Parameters examined were liquid and gas recirculation and configuration of diffusion devices. Moreover, the addition of packing materials as a mean to minimize the gas bubble size and thus increase the gas dissolution in the liquid was tested. Finally, the effect of gas retention time was evaluated using single or serial chamber configurations with different working volumes.

\section{Materials And Methods}

\subsection{Substrate characteristics and feedstock preparation}


Potato-starch wastewater substrate was obtained from Karup Kartoffelmelfabrik potato-starch processing factory, Denmark. Because potato-starch processing involves an up-concentration step, the provided substrate was diluted 10 times with water and Basal Anaerobic (BA) medium, to adjust the volatile solids (VS) content to the required operation conditions. Successively, the substrate was stored at $-20^{\circ} \mathrm{C}$, in $5 \mathrm{~L}$ bottles and thawed at $4^{\circ} \mathrm{C}$ for 2-3 days, before usage. BA medium was prepared as described in Supplementary Information (SI). The diluted substrate had a pH of 6.05, chemical oxygen demand (COD) of $21.76 \pm 0.15 \mathrm{~g} / \mathrm{L}$, total solids (TS) and VS content of $26.14 \pm 0.17$ and $18.73 \pm 0.12 \mathrm{~g} / \mathrm{L}$, respectively. The concentration of total volatile fatty acids (VFA) was 49.29 $\pm 4.94 \mathrm{mg} / \mathrm{L}$. Total Kjeldahl Nitrogen (TKN) and ammonium nitrogen $\mathrm{NH}^{+4}\left(\mathrm{NH}_{4}-\mathrm{N}\right)$ were $1.24 \pm 0.01$ and $0.30 \pm 0.01$ g-N/L, respectively.

\subsection{Setup and operation of the reactors}

Each setup was composed of a UASB reactor with a working volume of $1.4 \mathrm{~L}$, connected to a separate $\mathrm{H}_{2}$-injection chamber with a working volume of $0.2 \mathrm{~L}$. The feeding was introduced from the bottom of the UASB. The reactors were inoculated with 550 g of mesophilic granules, obtained from Colsen wastewater treatment plant treating potato starch wastewater (The Netherlands) and BA medium. The granules were adapted to thermophilic conditions for 25 days by feeding the reactors with diluted potato starch wastewater at hydraulic retention time (HRT) of 7 days and organic loading rate (OLR) of $2.79 \mathrm{gVS} / \mathrm{L}$.day. A double net-separator was located in the upper part of each UASB to prevent the wash out of granules. One setup (R1) was used as upgrading reactor, while the other (R2) was utilized as control reactor operated throughout the experiment without $\mathrm{H}_{2}$ injection. Both reactors were maintained at 
126 thermophilic conditions $\left(55 \pm 1^{\circ} \mathrm{C}\right.$ ) by circulating hot water through a water jacket 127 around the UASB reactors glass walls.

128 After the startup phase, the whole experiment was divided in 8 periods. During period I 129 the OLR was increased to 3.73 gVS/L day shortening the HRT to 5 days (Pre $\mathrm{H}_{2}$ phase).

130 The recirculation flow rate was set to $4 \mathrm{~L} / \mathrm{h}$. From period II, $\mathrm{H}_{2}$ was continuously injected to R1 through a diffuser placed at the bottom of the $\mathrm{H}_{2}$-injection chamber (Insitu phase). Rashig rings (5 mm internal diameter) were inserted into the separate chamber of both reactors to maximize the $\mathrm{H}_{2}$ gas-liquid mass transfer rate in case of R1. The volumetric $\mathrm{H}_{2}$ flow rate was set to 4 times the $\mathrm{CO}_{2}$ production rate (in the gas phase) recorded before the $\mathrm{H}_{2}$ addition, according to Luo and Angelidaki (2013b), i.e. 3.5 L/L.day, and then reduced to improve the $\mathrm{H}_{2}$ consumption. In period III, the recirculation flow rate of both reactors was increased to $7 \mathrm{~L} / \mathrm{h}$. Successively, in period IV, rashig rings were replaced by an inert alumina ceramic sponge, while in periods $\mathrm{V}$ and VI different gas recirculation flow were applied. In order to evaluate the effect of the gas retention time, the $\mathrm{H}_{2}$-injection chamber volume was doubled to $400 \mathrm{~mL}$ by connecting two chambers in series (Period VII) or by assembling them as a single chamber with extended length (Period VIII).

The percentage of $\mathrm{H}_{2}$ utilized was calculated according to the following equation (2):

$$
\mathrm{H}_{2} \text { utilization efficiency }=\frac{\mathrm{H}_{2} \text { injected }\left(\frac{\mathrm{L}}{\mathrm{L}-\text { day }}\right)-\mathrm{H}_{2} \text { in biogas }\left(\frac{\mathrm{L}}{\mathrm{L}-\text { day }}\right)}{\mathrm{H}_{2} \text { injected }\left(\frac{\mathrm{L}}{\mathrm{L}-\text { day }}\right)} * 100
$$

144 The percentage of $\mathrm{CH}_{4}$ derived from the conversion of $\mathrm{CO}_{2}$ and $\mathrm{H}_{2}$ was calculated 145 according to the equation 3: 
$\left(\frac{\left(\mathrm{CH}_{4} \text { production rate in } \mathrm{R} 1\left(\frac{\mathrm{L}}{\mathrm{L} . \text { day }}\right)-\mathrm{CH}_{4} \text { production rate in } \mathrm{R} 2\left(\frac{\mathrm{L}}{\mathrm{L} . d a y}\right)\right)}{\left.\mathrm{CH}_{4} \text { production rate in } \mathrm{R} 2\left(\frac{\mathrm{L}}{\mathrm{L} . d a y}\right)+\mathrm{CH}_{4} \text { production rate equivalent to VFA in } \mathrm{R} 2\left(\frac{\mathrm{L}}{\mathrm{L} \text {.day }}\right)\right)}+\right.$

$\frac{\left(\mathrm{CH}_{4} \text { production rate equivalent to VFA in } \mathrm{R} 1\left(\frac{\mathrm{L}}{\mathrm{L} . d a y}\right)-\mathrm{CH}_{4} \text { production rate equivalent to VFA in } \mathrm{R} 2\left(\frac{\mathrm{L}}{\mathrm{L} . d a y}\right)\right.}{\left.\mathrm{CH}_{4} \text { production rate in } \mathrm{R} 2\left(\frac{\mathrm{L}}{\mathrm{L} . \text { day }}\right)+\mathrm{CH}_{4} \text { production rate equivalent to VFA in } \mathrm{R} 2\left(\frac{\mathrm{L}}{\mathrm{L} \text {.day }}\right)\right)} * 100$

149 Where $\mathrm{CH}_{4}$ production rate represents the volume of $\mathrm{CH}_{4}$ produced per liter of reactor, per day, measured at the outflow of the reactor. While $\mathrm{CH}_{4}$ production rate equivalent to VFA was calculated converting VFA concentrations, in the reactors, to

$152 \mathrm{CH}_{4}$ production equivalent according the following conversion reactions:

Acetate

$\mathrm{CH}_{3} \mathrm{COOH}$

$\rightarrow \quad \mathrm{CH}_{4}+\mathrm{CO}_{2}$

Propionate
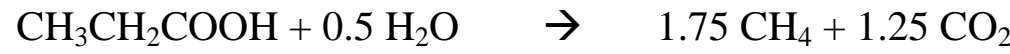

Butyrate
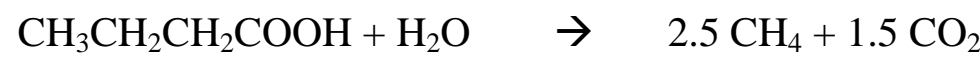

Valerate

$$
\mathrm{CH}_{3}\left(\mathrm{CH}_{2}\right)_{3} \mathrm{COOH}+1.5 \mathrm{H}_{2} \mathrm{O}
$$

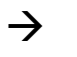

$3.25 \mathrm{CH}_{4}+1.75 \mathrm{CO}_{2}$

This was done to take into account the biomethanation inhibition caused by the injection of $\mathrm{H}_{2}$ in the upgrading reactor and provide a more accurate estimation of the $\mathrm{CH}_{4}$ produced from the conversion of $\mathrm{CO}_{2}$ and $\mathrm{H}_{2}$.

\subsection{Analytical methods}

The biogas production was recorded in daily basis. TS, VS, $\mathrm{NH}_{4}-\mathrm{N}$ and TKN were measured according to the Standard Methods for Examination of Water and Wastewater (APHA, 2005). Liquid samples from the reactors were collected for $\mathrm{pH}$ and VFA analysis every second day. VFA and pH were measured according to Kougias et al., (2015) as described in SI. Detailed description of chromatographs utilized to measure biogas composition and $\mathrm{CH}_{4}$ production (for batch assays) are given in SI. Detection limits for the measurement of $\mathrm{CH}_{4}, \mathrm{CO}_{2}$ and $\mathrm{H}_{2}$ by $\mathrm{GC}$ were defined by the calibration curve (5-100\%), while the detection limits for VFA were 5-1500 mg/L. 


\subsection{Specific methanogenic activity test}

172

173

\section{Results And Discussion}

\subsection{Process performances and biogas upgrade}

Operational data from upgrading (R1) and control (R2) reactor under steady state conditions are reported in Table 1 and 2.

\subsubsection{Period I: the pre $\mathrm{H}_{2}$ phase}

In the pre $\mathrm{H}_{2}$ phase (Period I), the two reactors showed similar performance in terms of biogas production rate (on average $2147 \mathrm{~mL} / \mathrm{L}$-reactor.day) and $\mathrm{CH}_{4}$ yield (335 $\mathrm{mL} / \mathrm{gVS}$, corresponding to $\sim 70 \%$ of the theoretical) (Table 1). This result is in accordance with previous studies on biogas production from starch biomasses (Frigon and Guiot, 2010). The average $\mathrm{CH}_{4}$ content of the reactors was 59\% (Table 1 and Fig. 1), the $\mathrm{pH}$ was $\sim 7.5$ and the total VFA content $>1 \mathrm{~g} / \mathrm{L}$ (Table 1 and Fig. 2). 


\subsubsection{Period II: effect of rashig rings as $\mathrm{H}_{2}$ distribution device on biogas upgrading} performance

To increase the $k_{L} a$ and thereby enhance gas-liquid transfer, rashig rings were placed in the $\mathrm{H}_{2}$-injection chamber to break $\mathrm{H}_{2}$ bubbles and thus increase contact surface area between gas and liquid phases (Kramer and Bailey, 1991). Once steady state conditions were achieved, $\mathrm{H}_{2}$ was continuously injected (3.5 L/L.day), through a metallic diffuser, in the $\mathrm{H}_{2}$-injection chamber (In-situ phase). By comparing reactors’ performance, in R1, 45\% higher $\mathrm{CH}_{4}$ production rate was observed (Table 1 and Fig. 3). Additionally, a pH increase to 7.9 was recorded in $\mathrm{R} 1$, as a result of the $\mathrm{CO}_{2}$ removal (Table 1 and Fig. 2a). Nevertheless, because of the low $\mathrm{H}_{2}$ gas-liquid mass transfer rate, only $51 \%$ of the $\mathrm{H}_{2}$ injected was utilized leading to a high amount of unutilized $\mathrm{H}_{2}$ in the output gas (45\%) (Table 1 and Fig 1a). Additionally, a remarkable increase in VFA levels, reaching 3.4 g/L, was recorded in the upgrading reactor, while VFA concentration in the control reactor remained stable (Table 1 and Fig. 2b). This is likely due to the high $\mathrm{H}_{2}$ partial pressure that affected negatively acidogenic VFA conversion resulting in their accumulation. Moreover, the continuous $\mathrm{H}_{2}$ injection led to a progressive higher $\mathrm{H}_{2}$ partial pressure, which shifted the metabolic pathway towards homoacetogenesis inhibiting methanogenesis (Cord-Ruwisch et al., 1997). This argument was supported by the predominance and accumulation of acetate over other VFA in R1 accounting for $55 \%$ of total VFA (Table 1). Moreover, this level was $4 \%$ higher than the correspondent level in R2, which, together with higher total VFA concentrations, demonstrates the instability caused by the excessive $\mathrm{H}_{2}$ flow rate provided in $\mathrm{R} 1$. Therefore, to provide a more accurate estimation of the increment of the $\mathrm{CH}_{4}$ production rate due to $\mathrm{CO}_{2}$ and $\mathrm{H}_{2}$ conversion, the total VFA concentrations in the two systems 
were converted in equivalent $\mathrm{CH}_{4}$ production, as described in section 2.2. The difference in the VFA concentration between the two reactors was taken into account to estimate the inhibition of liquid substrate degradation occurring in the upgrading reactor and allow the reactors' performances to be comparable. Thus, the $\mathrm{CH}_{4}$ derived from $\mathrm{CO}_{2}$ and

3) based on the difference between the $\mathrm{CH}_{4}$ production rates of the two systems after normalization of VFA.

To overcome the negative effect of the $\mathrm{H}_{2}$ on the biomethanation process and improve the $\mathrm{H}_{2}$ consumption, in the last part of this period the $\mathrm{H}_{2}$ flow rate was reduced to 2.6 L/L.day reducing the unutilized $\mathrm{H}_{2}$ to $34 \%$ of the output gas and increasing the $\mathrm{CH}_{4}$ content to $47 \%$.

\subsubsection{Period III: effect of liquid recirculation on upgrading performance}

$$
\text { Good mixing is known to be crucial to make substrates available for microorganisms }
$$
(Bhattacharyya and Singh, 2010; Luo and Angelidaki, 2012). Moreover good mixing increases the $k_{L} a$ for gasses, which is function of the surface area per unit volume, thereby increasing gas-liquid contact (Kramer and Bailey, 1991). Therefore, to improve $\mathrm{H}_{2}$-liquid contact, the liquid recirculation flow was increased from 4 to $7 \mathrm{~L} / \mathrm{h}$, while the $\mathrm{H}_{2}$ flow rate was maintained to $2.6 \mathrm{~L} / \mathrm{L}$.day leading to a slight increase of the utilized $\mathrm{H}_{2}$ (53\%) (Table1). The unutilized $\mathrm{H}_{2}$ and the $\mathrm{CH}_{4}$ content in the output gas stabilized to 37\% and 45\%, respectively (Table 1 and Fig. 1a). Similarly, in this period in R1 36\% higher $\mathrm{CH}_{4}$ production rate was recorded, compared to R2 (Table 1 and Fig. 3). As these results did not markedly differ from the last part of period I (i.e. $\mathrm{H}_{2}$ flow rate was reduced to $2.6 \mathrm{~L} / \mathrm{L}$.day), it can be concluded that the improved upgrading efficiency was mainly attributed to the lower $\mathrm{H}_{2}$ flow rate applied, rather than to the higher liquid 
recirculation flow. In fact, upon $\mathrm{H}_{2}$ addition, the granular bed appeared less expanded, probably due to reduced dissolved $\mathrm{CO}_{2}$ concentration in the liquid, due to the hydrogenotrophic consumption of $\mathrm{CO}_{2}$ to $\mathrm{CH}_{4}$ (Ohsumi et al., 1992; Song et al., 2005). Therefore, the positive effect of the higher liquid recirculation on biogas production and upgrading was not achieved.

\subsubsection{Period IV: effect of alumina ceramic sponge as $\mathrm{H}_{2}$ distribution device on} upgrading performance

An alternative method to reduce $\mathrm{H}_{2}$ bubbles size and thus increase gas-liquid contact is by increasing the surface area of the material over which the bubbles travelled and thereby breaking them to a smaller size. Based on that, the rashig rings in the $\mathrm{H}_{2}-$ injection chamber were replaced with alumina ceramic sponge. Alumina ceramic sponge introduced in the chamber had $16 \mathrm{~m}^{2}\left(0.3 \mathrm{~m}^{2} / \mathrm{g}\right)$ surface area which is significantly higher compared to the surface area in rashig rings $\left(0.1 \mathrm{~m}^{2}\right.$, corresponding to $0.002 \mathrm{~m}^{2} / \mathrm{g}$ ). Interestingly, in this period, the $\mathrm{H}_{2}$ utilization and the $\mathrm{CH}_{4}$ production rate derived from $\mathrm{CO}_{2}$ and $\mathrm{H}_{2}$ conversion increased (Table 1 and Fig. 3). On average, $67 \%$ of the $\mathrm{H}_{2}$ injected was utilized reducing the $\mathrm{H}_{2}$ content in the output gas to $31 \%$ and increasing the $\mathrm{CH}_{4}$ content to 52\% (Table 1 and Fig. 1a). These results clearly show the influence of the $\mathrm{H}_{2}$ distribution on the upgrading performances indicating the importance of porosity and pore size of the $\mathrm{H}_{2}$ distribution device for an effective $\mathrm{H}_{2}$ utilization by microorganisms.

In this period lower biogas and $\mathrm{CH}_{4}$ production rates were observed in particular in R2 (Table 1 and Fig. 3). Previous studies have demonstrated that aluminum oxide does not cause any toxic effects on microorganisms’ growth (Ingham et al., 2012). 
Additionally, state indicators of the biomethanation process, such as VFA and $\mathrm{pH}$, did not demonstrate any imbalance. More specifically, the VFA levels recorded in this period and particularly for R1 were at the lowest levels compared to the other periods (Table 1 and Fig. 2b). Therefore, we assume that ceramic sponge pores could have retained undigested biomass particles with consequent decrease of $\mathrm{CH}_{4}$ production.

In the last part of this period, in order to reduce the unutilized $\mathrm{H}_{2}$, the $\mathrm{H}_{2}$ flow rate was further decreased to $2 \mathrm{~L} / \mathrm{L}$.day resulting in reduced $\mathrm{H}_{2}$ and increased $\mathrm{CH}_{4}$ content in the output gas to $20 \%$ and $57 \%$, respectively.

\subsubsection{Period V and VI: effect of gas recirculation on upgrading performance}

As previously described, gas recirculation would have a positive effect on $k_{L} a$ coefficient, increasing $\mathrm{H}_{2}$ gas-liquid mass transfer rate (Equation 1) (Guiot et al., 2011). Therefore, in period V, $4 \mathrm{~mL} / \mathrm{min}$ gas recirculation (then increased to $6 \mathrm{~mL} / \mathrm{min}$, in period VI) were applied to R1 improving the $\mathrm{H}_{2}$ dissolution and thus significantly increasing the $\mathrm{CO}_{2}$ conversion. In fact, in these periods on average $87 \%$ of the $\mathrm{H}_{2}$ injected was utilized leading to 37\% higher $\mathrm{CH}_{4}$ production rate (Table 2 and Fig. 3). Nevertheless, an increase in the $\mathrm{pH}$ value to 8.2 was recorded as a result of the $\mathrm{CO}_{2}$ removal (Table 2 and Fig. 2a). The $\mathrm{CH}_{4}$ content in the biogas markedly increased to $66 \%$ and the unutilized $\mathrm{H}_{2}$ decreased to $14 \%$ (Table 2 and Fig. 1a). To further decrease the unutilized $\mathrm{H}_{2}$, at the end of the period the $\mathrm{H}_{2}$ flow rate was reduced to $1.8 \mathrm{~L} / \mathrm{L}$.day (corresponding to $\sim 2.5$ times the $\mathrm{CO}_{2}$ production rate recorded in R2). Nevertheless, no substantial difference in biogas composition and upgrading performances was recorded. In previous studies, $\mathrm{H}_{2}$ distribution in the reactor's liquid phase was optimized by the application of gas recirculation flow rates $\sim 4$-folds higher than the input gas flow rate 
289

290

291

292

293

294

295

296

297

298

299

300

301

302

303

304

305

306

307

308

309

310

311

(Díaz et al., 2015). Unfortunately, in this experiment, beside the positive effect on upgrading performances, the application of such a high gas recirculation flow rate led to an excessive pressure through the diffuser and to turbulent movements causing granules disintegration. The subsequent reduction of reactor's active biomass can explain the lower $\mathrm{CH}_{4}$ production rate and VFA levels higher than $5 \mathrm{~g} / \mathrm{L}$ observed in $\mathrm{R} 1$ from period V (Table 2, Fig. 2b and Fig. 3).

\subsubsection{Period VII and VIII: Effect of gas retention time using $\mathrm{H}_{2}$-injection chamber} configuration on upgrading process performance

To increase the contact area between $\mathrm{H}_{2}$ bubbles and liquid, and therefore increase $\mathrm{H}_{2}$ transfer coefficient (Equation 1), the ceramic sponge surface area was doubled. This was done by doubling $\mathrm{H}_{2}$-injection chamber volume, either by connecting two chambers in series (Period VII), or by assembling them in a single longer chamber (Period VIII). The connection of two chambers in series did not lead to a substantial improvement of upgrading performances, indicating that chamber's volume itself has not a direct correlation with $\mathrm{H}_{2}$ distribution. Nevertheless, by assembling two chambers in a single longer one, a higher $\mathrm{H}_{2}$ percentage was utilized (94\%) resulting in only $8 \% \mathrm{H}_{2}$ unutilized (Table 2 and Fig. 1a). Therefore, $\mathrm{CO}_{2}$ and $\mathrm{CH}_{4}$ contents in the output biogas dropped to $10 \%$ and increased to $81 \%$ (with a maximum of $82 \%$ ) respectively (Table 2 and Fig. 1a). However, in this period the $\mathrm{pH}$ raised to 8.4 as a consequence of the high $\mathrm{CO}_{2}$ conversion (Table2 and Fig. 2a). The results clearly demonstrate the importance of a proper reactor configuration design that increases the gas retention time leading to more efficient $\mathrm{H}_{2}$ distribution and $\mathrm{CO}_{2}$ conversion to $\mathrm{CH}_{4}$. 
Moreover, from the comparison of reactors $\mathrm{CH}_{4}$ production rate, it was shown that, in the upgrading reactor, on average the $\mathrm{CH}_{4}$ produced from the conversion of $\mathrm{CO}_{2}$ represented $\sim 37 \%$ of the total recorded $\mathrm{CH}_{4}$ production rate (Table 1 and 2 and Fig. 3).

315 Finally, it should be mentioned that the lower $\mathrm{CH}_{4}$ production and higher VFA levels of control reactor observed in period VII were due to the disassembly of the separate chamber in order to be mounted in the upgrading reactor (Table 2 and Fig. 2b and 3). The $\mathrm{CH}_{4}$ productivity and the VFA concentration of the control reactor were recovered in period VIII.

\subsection{Specific methanogenic activity test}

$\mathrm{H}_{2}$ addition is known to promote the hydrogenotrophic methanogenic pathway (Bassani et al., 2015; Luo and Angelidaki, 2013a, 2013b). Therefore, in this experiment, SMA tests were performed to validate the effect of the $\mathrm{H}_{2}$ addition on methanogenesis pathways. Granules and liquid samples were taken from the reactors at steady state of periods IV (introduction of ceramic sponge as $\mathrm{H}_{2}$ distribution device) and V (application of gas recirculation). It was shown that the preferable methanogenic pathway in both reactors (i.e. R1 and R2) was hydrogenotrophic (Table 3). This result was expected because hydrogenotrophic methanogens are known to be predominant in starch-grown granules (Lu et al., 2015). In period IV, $\mathrm{CH}_{4}$ production rate achieved by batches fed with $\mathrm{H}_{2} / \mathrm{CO}_{2}$ did not show markedly difference between the two reactors. Conversely, in period V, higher hydrogenotrophic activity was observed in R1 compared to the control reactor, likely due to the gas recirculation enhancing the effect of $\mathrm{H}_{2}$ addition on microbial community composition and thus stimulating hydrogenotrophic methanogenic pathway. 
336 Both tests showed low aceticlastic activity which can be explained by the high acetate

337 levels detected in the reactors before the tests which further increased in period V ( 3.3

$338 \mathrm{~g} / \mathrm{L}$ in R1 and $\sim 1.5 \mathrm{~g} / \mathrm{L}$ in R2; Table 2). Moreover, by comparing the concentration of

339 unutilized acetate at the end of SMA tests and in the UASB reactors, it was shown that

340 acetate levels markedly decreased in all batches (from 3 to $2.5 \mathrm{~g} / \mathrm{L}$ in the upgrading

341 system and from 1.4 to $1.3 \mathrm{~g} / \mathrm{L}$ in the control treatment), apart from batches fed with

342 acetate, where acetate levels increased to 3.3 and $1.8 \mathrm{~g} / \mathrm{L}$ in R1 and R2, respectively.

343 These results indicate that high acetate levels in the inoculum obtained from the reactor

344 probably inhibited the process not allowing the further degradation of the supplemental

345 amount of acetate that was added in the batch bottles (Gorris et al., 1989).

346 Finally, it was found that the specific microbial activity for the degradation of glucose

347 was lower in period V compared to period IV. This could be possibly due to the

348 negative effect of gas recirculation on the granules as previously discussed in the

349 continuous reactor operation (Tables 1, 2 and 3).

\section{Conclusions}

The current research demonstrated the feasibility of in-situ biogas upgrading using an external chamber with $25 \%$ of the conventional biogas reactor volume. Key factors affecting the $\mathrm{H}_{2}$ gas-liquid mass transfer rate were tested to improve the efficiency of the overall process. It was shown that the use of porous devices benefit the $\mathrm{H}_{2}$ uptake as the active contact area is increasing and the gas retention time is extended. Moreover, the gas recirculation flow rate and the chamber design are fundamental elements that must be considered to maximize the gas retention time and thus the $\mathrm{H}_{2}$ dissolution to the liquid media. 
Acknowledgments

We thank Hector Garcia and Hector Diaz for technical assistance. This work was supported by the Danish Council for Strategic Research under the project "SYMBIOIntegration of biomass and wind power for biogas enhancement and upgrading via hydrogen assisted anaerobic digestion”, contract 12-132654.

\section{Appendix A. Supplementary data}

Supplementary data associated with this article can be found, in the online version, at

\section{References}

1. Abeling, U., Seyfried, C.F., 1993. Anaerobic-aerobic treatment of potato-starch wastewater. Water Sci. Technol. 28, 165-176.

2. APHA, 2005. Standard Methods for the Examination of Water and Wastewater, Environment Federation.

3. Barampouti, E.M.P., Mai, S.T., Vlyssides, A.G., 2005. Dynamic modeling of biogas production in an UASB reactor for potato processing wastewater treatment. Chem. Eng. J. 106, 53-58.

4. Bassani, I., Kougias, P.G., Treu, L., Angelidaki, I., 2015. Biogas Upgrading via Hydrogenotrophic Methanogenesis in Two-Stage Continuous Stirred Tank Reactors at Mesophilic and Thermophilic Conditions. Environ. Sci. Technol. 49, 1258512593. 
5. Bhattacharyya, D., Singh, K.S., 2010. Understanding the Mixing Pattern in an Anaerobic Expanded Granular Sludge Bed Reactor: Effect of Liquid Recirculation. J. Environ. Eng. 136, 576-584.

6. Cord-Ruwisch, R., Mercz, T.I., Hoh, C.Y., Strong, G.E., 1997. Dissolved hydrogen concentration as an on-line control parameter for the automated operation and optimization of anaerobic digesters. Biotechnol. Bioeng. 56, 626-634.

7. Deng, L., Hägg, M.B., 2010. Techno-economic evaluation of biogas upgrading process using $\mathrm{CO}_{2}$ facilitated transport membrane. Int. J. Greenh. Gas Control. 4, 638-646.

8. Díaz, I., Pérez, C., Alfaro, N., Fdz-Polanco, F., 2015. A feasibility study on the bioconversion of $\mathrm{CO}_{2}$ and $\mathrm{H}_{2}$ to biomethane by gas sparging through polymeric membranes. Bioresour. Technol. 185, 246-53.

9. Frigon, J.C., Guiot, S.R., 2010. Biomethane production from starch and lignocellulosic crops: A comparative review. Biofuels, Bioprod. Biorefining. 4, 447458.

10. Gomec, C.Y., 2010. High-rate anaerobic treatment of domestic wastewater at ambient operating temperatures: A review on benefits and drawbacks. J. Environ. Sci. Health. A. Tox. Hazard. Subst. Environ. Eng. 45, 1169-1184.

11. Gorris, L.G.M., van Deursen, J.M.A., van der Drift, C., Vogels, G.D., 1989. Inhibition of propionate degradation by acetate in methanogenic fluidized bed reactors. Biotechnol. Lett. 11, 61-66.

12. Guiot, S.R., Cimpoia, R., Carayon, G., 2011. Potential of wastewater-treating anaerobic granules for biomethanation of synthesis gas. Environ. Sci. Technol. 45, 2006-2012. 
13. Ingham, C.J., ter Maat, J., de Vos, W.M., 2012. Where bio meets nano: The many uses for nanoporous aluminum oxide in biotechnology. Biotechnol. Adv. 30, 10891099.

14. Kougias, P.G., Boe, K., Einarsdottir, E.S., Angelidaki, I., 2015. Counteracting foaming caused by lipids or proteins in biogas reactors using rapeseed oil or oleic acid as antifoaming agents. Water Res. 79, 119-27.

15. Kramer, H.W., Bailey, J.E., 1991. Mass transfer characterization of an airlift probe for oxygenating and mixing cell suspensions in an NMR spectrometer. Biotechnol. Bioeng. 37, 205-209.

16. Lu, X., Zhen, G., Estrada, A.L., Chen, M., Ni, J., Hojo, T., Kubota, K., Li, Y.Y., 2015. Operation performance and granule characterization of upflow anaerobic sludge blanket (UASB) reactor treating wastewater with starch as the sole carbon source. Bioresour. Technol. 180, 264-273.

17. Luo, G., Angelidaki, I., 2012. Integrated biogas upgrading and hydrogen utilization in an anaerobic reactor containing enriched hydrogenotrophic methanogenic culture. Biotechnol. Bioeng. 109, 2729-2736.

18. Luo, G., Angelidaki, I., 2013. Co-digestion of manure and whey for in situ biogas upgrading by the addition of $\mathrm{H}_{2}$ : Process performance and microbial insights. Appl. Microbiol. Biotechnol. 97, 1373-1381.

19. Luo, G., Johansson, S., Boe, K., Xie, L., Zhou, Q., Angelidaki, I., 2012. Simultaneous hydrogen utilization and in situ biogas upgrading in an anaerobic reactor. Biotechnol. Bioeng. 109, 1088-1094. 
20. Muñoz, R., Meier, L., Diaz, I., Jeison, D., 2015. A review on the state-of-the-art of physical/chemical and biological technologies for biogas upgrading. Rev. Environ. Sci. Biotechnol. 14, 727-759.

21. Nizami, A.S., Orozco, A., Groom, E., Dieterich, B., Murphy, J.D., 2012. How much gas can we get from grass? Appl. Energy. 92, 783-790.

22. Nordberg, Å., Edström, M., Uusi-Penttilä, M., Rasmuson, Å.C., 2012. Selective desorption of carbon dioxide from sewage sludge for in-situ methane enrichment: Enrichment experiments in pilot scale. Biomass and Bioenergy. 37, 196-204.

23. Ohsumi, T., Nakashiki, N., Shitashima, K., Hirama, K., 1992. Density change of water due to dissolution of carbon dioxide and near-field behavior of $\mathrm{CO}_{2}$ from a source on deep-sea floor. Energy Convers. Manag. 33, 685-690.

24. Pauss, A., Andre, G., Perrier, M., Guiot, S.R., 1990. Liquid-to-Gas mass transfer in anaerobic processes: Inevitable transfer limitations of methane and hydrogen in the biomethanation process. Appl. Environ. Microbiol. 56, 1636-1644.

25. Powar, M.M., Kore, V.S., Kore, S. V, Kulkarni, G.S., 2013. Review on Applications of Uasb Technology for Wastewater Treatment. Int. J. Adv. Sci. Eng. Technol. 2, $125-133$.

26. Sevilla-Espinosa, S., Solórzano-Campo, M., Bello-Mendoza, R., 2010. Performance of staged and non-staged up-flow anaerobic sludge bed (USSB and UASB) reactors treating low strength complex wastewater. Biodegradation. 21, 737-751.

27. Song, Y., Chen, B., Nishio, M., Akai, M., 2005. The study on density change of carbon dioxide seawater solution at high pressure and low temperature. Energy. 30, 2298-2307. 
453 28. Weiland, P., 2010. Biogas production: current state and perspectives. Appl.

$454 \quad$ Microbiol. Biotechnol. 85, 849-860.

455 29. Zheng, M.X., Wang, K.J., Zuo, J.E., Yan, Z., Fang, H., Yu, J.W., 2012. Flow pattern

456 analysis of a full-scale expanded granular sludge bed-type reactor under different

457 organic loading rates. Bioresour. Technol. 107, 33-40. 
458 Table captions:

459 Table 1: Upgrading (R1) and control (R2) reactor performances under steady state 460 conditions (Periods I-IV).

461 Table 2: Upgrading (R1) and control (R2) reactor performances under steady state 462 conditions (Periods V-VIII).

463 Table 3: Specific methanogenic activity (SMA) results, expressed as $\mathrm{CH}_{4}$ production 464 rate (mL/L.day), under steady state conditions. 
465 Figure captions:

466 Fig. 1: Biogas composition $\left(\mathrm{CH}_{4}(\bullet), \mathrm{CO}_{2}(\circ)\right.$ and $\left.\mathrm{H}_{2}(\mathbf{\bullet}) \%\right)$ of (a) upgrading and (b) 467 control reactor.

468 Fig. 2: $\mathrm{pH}(\mathrm{a})$ and total VFA (b) of upgrading ( $\bullet$ ) and control (०) reactor.

469 Fig. 3: $\mathrm{CH}_{4}$ production rate of upgrading ( $\left.\downarrow\right)$ and control (०) reactor. 


\section{Table 1}

\begin{tabular}{|c|c|c|c|c|c|c|c|c|}
\hline Phase & \multicolumn{2}{|c|}{ Pre $\mathrm{H}_{2}$} & \multicolumn{6}{|c|}{ In-situ } \\
\hline Period & \multicolumn{2}{|c|}{$\mathrm{I}$} & \multicolumn{2}{|c|}{ II } & \multicolumn{2}{|c|}{ III } & \multicolumn{2}{|c|}{ IV } \\
\hline $\mathrm{H}_{2}$ distribution device & \multicolumn{2}{|c|}{ - } & \multicolumn{2}{|c|}{ rashig rings } & \multicolumn{2}{|c|}{ rashig rings } & \multicolumn{2}{|c|}{ ceramic sponge } \\
\hline Reactor & $\mathrm{R} 1$ & $\mathrm{R} 2$ & $\mathrm{R} 1$ & R2 & $\mathrm{R} 1$ & R2 & $\mathrm{R} 1$ & $\mathrm{R} 2$ \\
\hline Liquid recirculation flow (L/h) & 4 & 4 & 4 & 4 & 7 & 7 & 7 & 7 \\
\hline Gas recirculation flow (mL/min) & NA* & / & NA* & / & NA* & / & NA* & / \\
\hline Biogas production rate (mL/L.day) & $2167 \pm 180$ & $2127 \pm 180$ & $2093 \pm 232$ & $2229 \pm 129$ & $2072 \pm 102$ & $2015 \pm 75$ & $1953 \pm 97$ & $1787 \pm 57$ \\
\hline \multicolumn{9}{|l|}{ Biogas composition (\%): } \\
\hline $\mathrm{CH}_{4}$ & $58.2 \pm 3.4$ & $60.3 \pm 3.0$ & $40.4 \pm 4.3$ & $60.6 \pm 1.8$ & $44.9 \pm 2.3$ & $60.9 \pm 1.0$ & $52.0 \pm 1.9$ & $62.5 \pm 0.3$ \\
\hline $\mathrm{CO}_{2}$ & $41.8 \pm 3.4$ & $39.7 \pm 3.0$ & $14.9 \pm 3.2$ & $39.4 \pm 1.8$ & $18.5 \pm 3.2$ & $39.1 \pm 1.0$ & $17.0 \pm 0.7$ & $37.5 \pm 0.3$ \\
\hline $\mathrm{H}_{2}$ & NA* & / & $44.6 \pm 6.7$ & / & $36.6 \pm 1.9$ & / & $31.0 \pm 1.9$ & / \\
\hline $\mathrm{CH}_{4}$ production rate (mL/L.day) & $1255 \pm 54$ & $1277 \pm 61$ & $1528 \pm 147$ & $1350 \pm 74$ & $1497 \pm 73$ & $1227 \pm 53$ & $1471 \pm 72$ & $1117 \pm 39$ \\
\hline $\mathrm{CO}_{2}$ in output gas (mL/L.day) & $912 \pm 148$ & $850 \pm 134$ & $565 \pm 115$ & $878 \pm 73$ & $618 \pm 55$ & $789 \pm 33$ & $482 \pm 34$ & $670 \pm 19$ \\
\hline
\end{tabular}




$\begin{array}{lcccccccc}\mathrm{H}_{2} \text { flow rate (mL/L.day) } & \mathrm{NA} * & / & 3477 \pm 594 & / & 2636 \pm 89 & / & 2629 \pm 93 & / \\ \mathrm{H}_{2} \text { consumption rate (mL/L.day) } & \mathrm{NA} * & / & 1769 \pm 330 & / & 1412 \pm 212 & / & 1756 \pm 121 & / \\ \mathrm{pH} & 7.46 \pm 0.03 & 7.49 \pm 0.06 & 7.92 \pm 0.11 & 7.59 \pm 0.09 & 7.90 \pm 0.06 & 7.60 \pm 0.05 & 7.93 \pm 0.12 & 7.56 \pm 0.09 \\ \text { Total VFA (g/L) } & 1.69 \pm 0.37 & 1.21 \pm 0.25 & 3.40 \pm 0.31 & 1.41 \pm 0.28 & 3.60 \pm 0.23 & 2.26 \pm 0.11 & 2.81 \pm 0.46 & 2.37 \pm 0.32 \\ \text { Acetate content in VFA (\%) } & 41.3 \pm 4.3 & 49.0 \pm 3.9 & 55.3 \pm 4.0 & 51.5 \pm 3.8 & 51.8 \pm 2.3 & 47.3 \pm 3.7 & 49.7 \pm 3.8 & 47.2 \pm 4.2 \\ & & & & & & & & \end{array}$

*NA: not applicable to this period 


\section{Table 2}

\begin{tabular}{|c|c|c|c|c|c|c|c|c|}
\hline Phase & & & & In- & & & & \\
\hline$\overline{\text { Period }}$ & & & T & $\overline{I I}$ & & II & $\mathrm{V}$ & III \\
\hline $\mathrm{H}_{2}$ distribution device & ceramic & sponge & ceramic & sponge & serial c & hambers & $\begin{array}{r}\text { single cha } \\
\text { extende }\end{array}$ & $\begin{array}{l}\text { mber with } \\
\text { d length }\end{array}$ \\
\hline Reactor & R1 & $\mathrm{R} 2$ & R1 & $\mathrm{R} 2$ & R1 & $\mathrm{R} 2$ & R1 & $\mathrm{R} 2$ \\
\hline 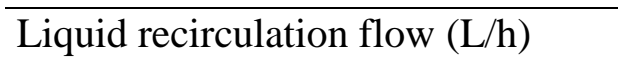 & 7 & 7 & 7 & 7 & 7 & 7 & 7 & 7 \\
\hline Gas recirculation flow (mL/min) & 4 & / & 6 & l & 6 & / & 6 & / \\
\hline Biogas production rate (mL/L.day) & $1786 \pm 68$ & $1900 \pm 85$ & $1521 \pm 98$ & $2018 \pm 275$ & $1337 \pm 72$ & $1175 \pm 138$ & $1261 \pm 157$ & $1558 \pm 188$ \\
\hline Biogas composition (\%): & & & & & & & & \\
\hline $\mathrm{CH}_{4}$ & $66.4 \pm 1.9$ & $61.1 \pm 1.2$ & $66.0 \pm 2.5$ & $65.0 \pm 2.4$ & $67.6 \pm 2.0$ & $65.0 \pm 1.0$ & $81.3 \pm 0.6$ & $66.7 \pm 2.8$ \\
\hline $\mathrm{CO}_{2}$ & $20.5 \pm 4.0$ & $38.9 \pm 1.2$ & $18.35 \pm 3.9$ & $35.0 \pm 2,4$ & $18.8 \pm 0.5$ & $35.0 \pm 1.0$ & $10.2 \pm 1.0$ & $33.2 \pm 2.8$ \\
\hline $\mathrm{H}_{2}$ & $13.0 \pm 4.3$ & / & $15.7 \pm 1.4$ & / & $13.5 \pm 2.4$ & / & $8.5 \pm 1.5$ & / \\
\hline $\mathrm{CH}_{4}$ production rate (mL/L.day) & $1365 \pm 52$ & $1161 \pm 55$ & $1188 \pm 55$ & $1308 \pm 149$ & $1046 \pm 57$ & $763 \pm 92$ & $1145 \pm 134$ & $1039 \pm 121$ \\
\hline
\end{tabular}




$\begin{array}{lcccccccc}\mathrm{CO}_{2} \text { in output gas (mL/L.day) } & 421 \pm 65 & 740 \pm 47 & 333 \pm 82 & 710 \pm 134 & 291 \pm 16 & 412 \pm 48 & 121 \pm 21 & 615 \pm 83 \\ \mathrm{H}_{2} \text { flow rate (mL/L.day) } & 2144 \pm 312 & / & 1834 \pm 30 & / & 1768 \pm 55 & / & 1828 \pm 14 & / \\ \mathrm{H} & 1873 \pm 234 & / & 1551 \pm 44 & / & 1536 \pm 80 & / & 1717 \pm 23 & / \\ \mathrm{HH} & 7.83 \pm 0.10 & 7.64 \pm 0.07 & 8.24 \pm 0.20 & 7.85 \pm 0.12 & 8.18 \pm 0.08 & 7.92 \pm 0.07 & 8.38 \pm 0.07 & 7.99 \pm 0.09 \\ \text { Total VFA (g/L) } & 5.11 \pm 0.06 & 3.24 \pm 0.48 & 3.66 \pm 0.97 & 2.37 \pm 0.27 & 4.34 \pm 0.40 & 3.21 \pm 0.39 & 3.87 \pm 0.40 & 2.36 \pm 0.15 \\ \text { Acetate content in VFA (\%) } & 64.6 \pm 3.4 & 46.0 \pm 4.7 & 39.9 \pm 2.6 & 39.4 \pm 4.3 & 37.0 \pm 2.2 & 36.5 \pm 2.9 & 30.3 \pm 1.4 & 34.5 \pm 6.5\end{array}$


Table 3

\begin{tabular}{lcccc}
\hline Period & \multicolumn{2}{c}{ IV } & \multicolumn{2}{c}{ V } \\
\hline Reactor & $\mathrm{R} 1$ & $\mathrm{R} 2$ & $\mathrm{R} 1$ & $\mathrm{R} 2$ \\
\hline Blank & $36 \pm 2$ & $11 \pm 2$ & $6 \pm 1$ & $7 \pm 1$ \\
Glucose & $589 \pm 67$ & $219 \pm 6$ & $73 \pm 22$ & $23 \pm 12$ \\
Acetate & $159 \pm 4$ & $4 \pm 1$ & $4 \pm 1$ & $3 \pm 2$ \\
$\mathrm{H}_{2} / \mathrm{CO}_{2}$ & $1270 \pm 20$ & $1296 \pm 29$ & $986 \pm 212$ & $520 \pm 65$
\end{tabular}




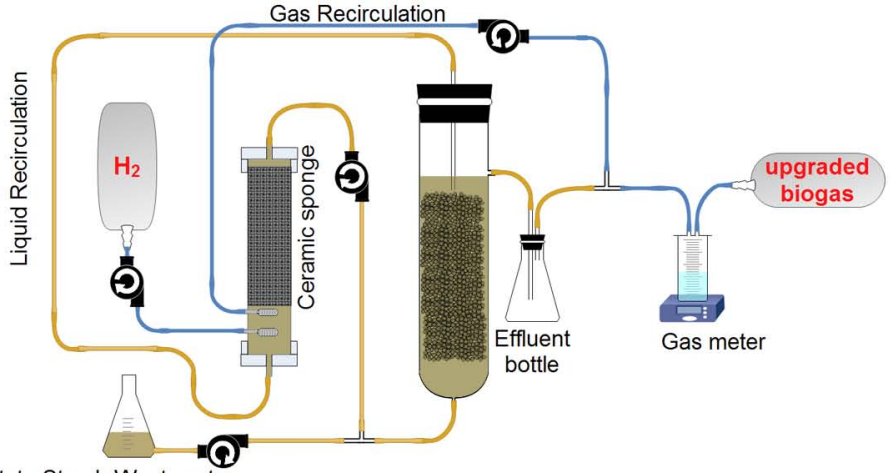

Potato Starch Wastewater 
a)

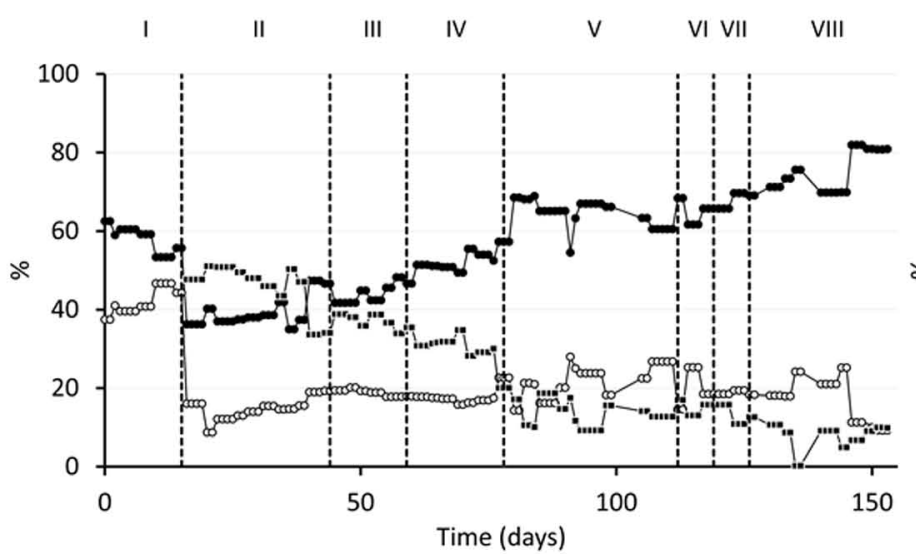

b)

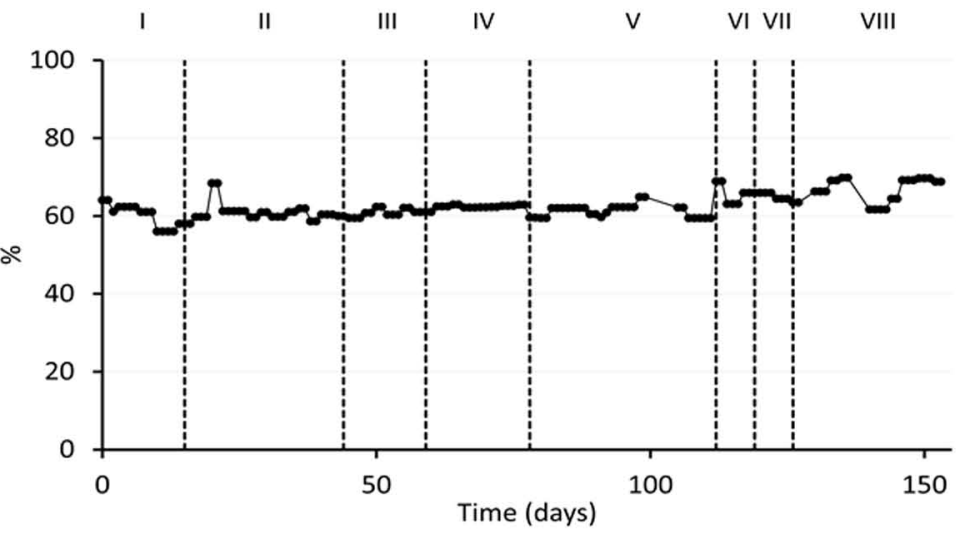


a)

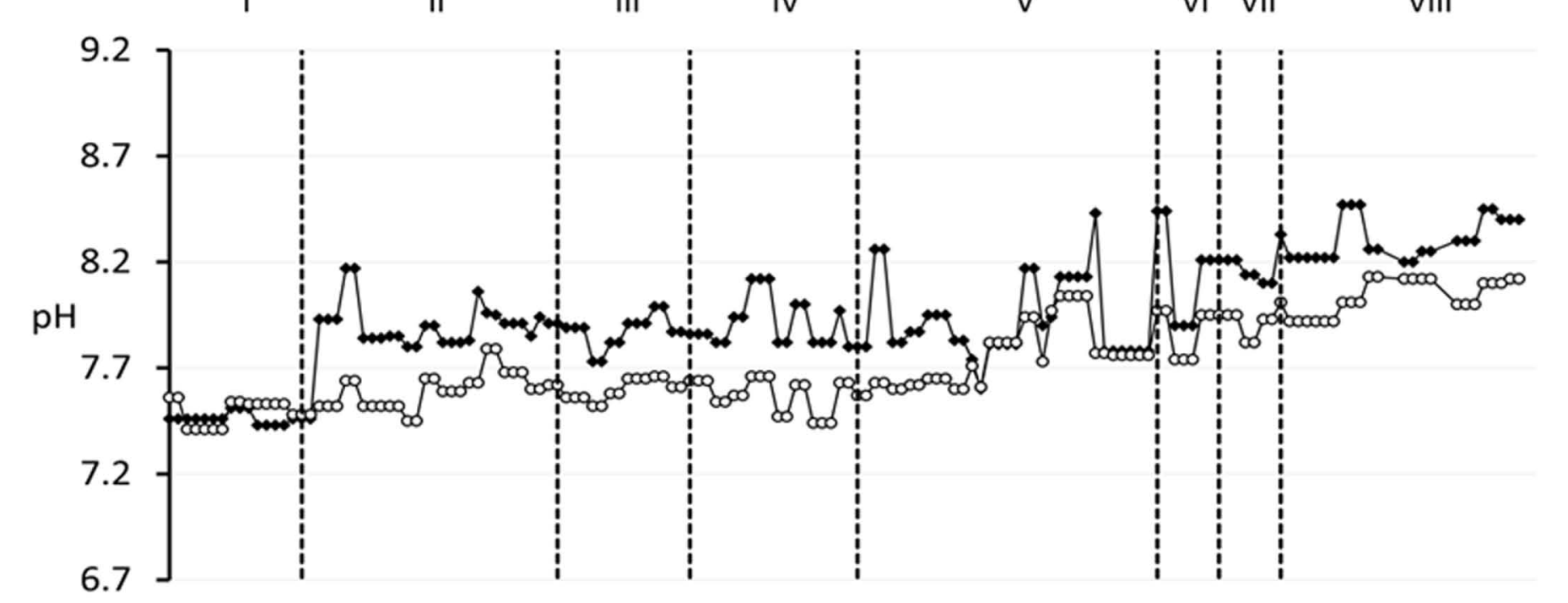

b)

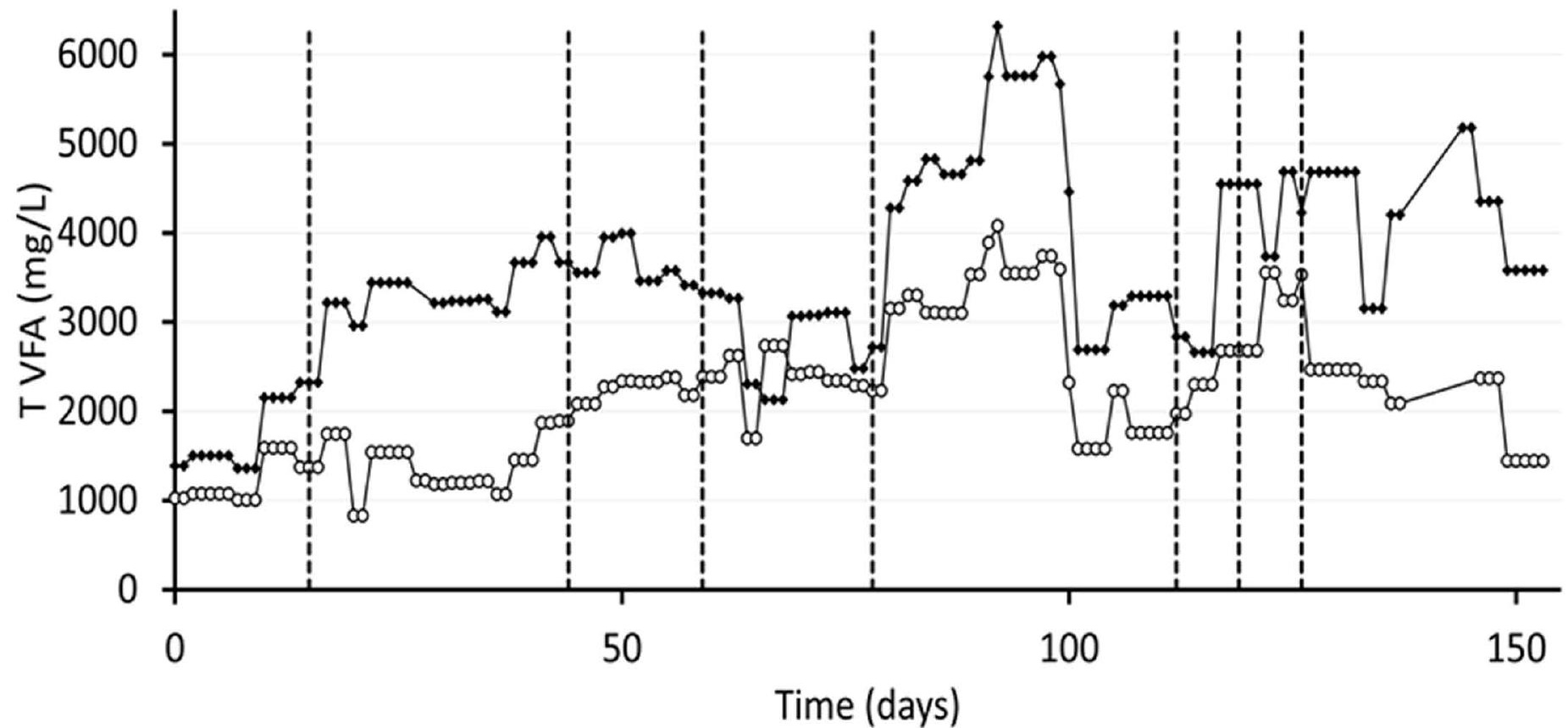


$\begin{array}{lllllll}I I & \text { III } & \text { IV } & \text { V } & \text { VI VII } & \text { VIII }\end{array}$

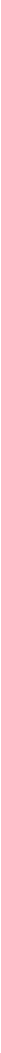

